\title{
Towards a Standardized User Model for Personalized Systems in Health
}

Carolina Rico Olarte / carolinarico@unicauca.edu.co

Edwar Javier Girón Buitrón / edwardgb@unicauca.edu.co

Gineth Magaly Cerón Ríos, Ph.D.(c) / gceron@unicauca.edu.co

Diego Mauricio López Gutiérrez, Ph.D. / dmlopez@unicauca.edu.co

Universidad del Cauca, Popayán-Colombia

ABSTRACT The definition of a user model supports personalization in computer-based systems. For a personalized system in health, which supports the promotion of healthy habits and lifestyles, in particular physical activity and healthy diet, a user model according to the ISO/TR 14292 standard for Personal Health Records [PHR] is proposed. The description of the standardized user model includes: a characterization of the user model; the proposed user model according to the ISO standard; the relationships and inferences of the user model; and reference architecture for the system to be developed. Finally, a prototype with a small dataset is implemented and some possible mockups supporting the proposed architecture are designed.

KEYWORDS User model, PHR, personalized systems, promotion in health, physical activity, healthy diet.

\section{Hacia un modelo de usuario estándar} para sistemas de salud personalizados

RESUMEN La definición de un modelo de usuario es el soporte de la personalización en los sistemas computacionales. Para un sistema personalizado en salud, el cual soporta la promoción de hábitos y estilos de vida saludables, en particular la actividad física y la dieta saludable; se propone un modelo de usuario de acuerdo con el estándar ISO/TR 14292 para los PHR (Personal Health Record). La descripción del modelo de usuario estandarizado incluye: una caracterización del modelo de usuario; el modelo de usuario propuesto de acuerdo con la norma ISO; las relaciones e inferencias del modelo de usuario; y una arquitectura de referencia para el sistema a desarrollar. Finalmente, se implementa un prototipo con un pequeño conjunto de datos y se diseñan algunos posibles mockups, como soporte a la arquitectura propuesta.

PALABRAS CLAVE Modelo de usuario, PHR, sistemas personalizados, promoción en salud, actividad física, dieta saludable.
Rumo a um modelo de usuário standard para sistemas de saúde personalizados

RESUMO A definição de um modelo de usuário é o suporte para a personalização nos sistemas informáticos. Para um sistema personalizado de saúde, que apoia a promoção de hábitos e estilos de vida saudáveis, em particular a atividade física e dieta saudável; é proposto um modelo de usuário em conformidade com a norma ISO/TR 14292 para os PHR (Personal Health Re(ord). A descrição do modelo de usuário standard inclui: uma caracterização do modelo de usuário; o modelo de usuário proposto de acordo com a norma ISO; as relações e inferências do modelo de usuário; e uma arquitetura de referência para o sistema a ser desenvolvido. Finalmente, é implementado um protótipo com um pequeno conjunto de dados e são desenhados alguns possíveis mockups, como apoio à arquitetura proposta.

PALAVRAS-CHAVE Modelo de usuário, sistemas personalizados, promoção da saúde; atividade física e dieta saudável. 


\section{Introduction}

The pace of life of a ordinary person brings behavioral changes that are considered risk factors affecting their health and their performance in the different environments in which they operate daily, and cause imbalances in his or her health (Leka, 2004); these factors threaten the health of people and contribute to increased incidence of chronic diseases. In order to reduce these risk factors, global studies have been conducted on using supported in Information and Communication Technology [ICT], in order to promote habits and healthy lifestyles, affecting positively the health of people. Interventions considered effective must be guaranteed beforehand; for example, good quality software used in the operation, in terms of performance, efficiency and usability.

Nowadays the number of ICT interventions available has increased considerably (Slootmaker, Paw, Schuit, Seidell, \& Van Mechelen, 2005), however, a few of them have shown the ability to be customized or adapted to the particular characteristics of each user. Du, Youngblood and Pirolli (2014) have an ICT platform that recommends interventions to reduce stress; this platform, known as Fittle, is personalized and takes into account the interests and personal characteristics of each user these data are the basis for making recommendations; after the evaluation of the platform with health professionals was done, it was shown that there was an increase in commitment and efficacy through diet, physical activity and stress reduction; there was an increase in the time of adherence and it was found that changes in behavior were more obvious than with other non-personalized interventions.

Not having a personalized system that automates the ICT process of recommendation of interventions brings a problem to potential users of such interventions, due to the person choosing to accept and adapt to any intervention, rather than searching, finding and using what he or she requires, from their personal characteristics, needs and interests. For this reason it is recommended to have personalized systems to promote habits and healthy lifestyles, based on a user model that collects, manages and lists the personal data of each user, in order to meet its key aspects and that data conform to a standard electronic record of personal health, as there is a need to manage the clinical data of people.

\section{Introducción}

El ritmo de vida actual de una persona promedio trae consigo alteraciones del comportamiento que son consideradas como factores de riesgo que afectan su salud y su desempeño en los distintos entornos en los que se desenvuelve diariamente, y ocasionan desequilibrios en su salud (Leka, 2004); estos factores amenazan la salud de las personas y contribuyen a incrementar la incidencia de enfermedades crónicas. Con el fin de disminuir tales factores de riesgo, se han venido realizando estudios globalmente acerca del uso de intervenciones soportadas en Tecnologías de la Información y las Comunicaciones [TIC], para la promoción de hábitos y estilos de vida saludables, que afecten de manera positiva la salud de las personas. Las intervenciones consideradas como efectivas deben ser garantizadas de manera previa, por ejemplo, contar con una buena calidad del producto software usado en la intervención, en términos de su desempeño, eficiencia y usabilidad.

Actualmente el número de intervenciones TIC disponibles se ha incrementado considerablemente (Slootmaker, Paw, Schuit, Seidell, \& Van Mechelen, 2005), sin embargo, pocas de ellas han demostrado la capacidad de ser personalizables o adaptables a las características particulares de cada usuario. Du, Youngblood, y Pirolli (2014) presentan una plataforma que recomienda intervenciones TIC para reducir el estrés; esta plataforma, conocida como Fittle, es personalizada y tiene en cuenta los intereses y algunas características personales de cada usuario - estos datos son la base para hacer las recomendaciones-; después de realizar la evaluación de la plataforma con profesionales de salud, se demostró que aumentaba el compromiso y la eficacia a través de dieta, actividad física y reducción de estrés; hubo un aumento en el tiempo de adherencia y se comprobó que los cambios de comportamiento eran más evidentes que con otro tipo de intervención no personalizada.

No contar con un sistema personalizado que permita automatizar el proceso de recomendación de intervenciones TIC trae consigo un problema a los posibles usuarios de dichas intervenciones, pues la persona opta por aceptar y adaptarse a cualquier intervención, en lugar de buscar, encontrar y utilizar aquella que él requiera, a partir de sus características personales, sus necesidades y sus intereses. Por esta razón es recomendable tener sistemas personalizados para la promoción de hábitos y estilos de vida saludables, basados en un modelo de usuario que recolecte, maneje y relacione los datos personales de cada usuario, para lograr conocer sus aspectos clave y que los daros se encuentren conformes conforme a un registro electrónico de salud personal estándar, ya que existe la necesidad de gestionar los datos clínicos de una persona.

En este artículo se describe cómo debe ser el modelo de usuario conforme a la norma ISO/TR 14292 para un sistema personalizado, como apoyo a la promoción de la actividad física y una dieta saludable, en el marco de la promoción de hábitos y estilos de vida saludables.

El presente artículo está estructurado así: la primera sección abarca los trabajos relacionados, la segunda describe el mar- 
co conceptual en el que se basa este artículo y la la tercera describe la metodología usada para la investigación; la cuarta muestra los resultados de este trabajo, los cuales están divididos en: caracterización del modelo de usuario, modelo de usuario conforme a la norma ISO/TR 14292, relaciones e inferencias del modelo de usuario, propuesta de una arquitectura de referencia para el sistema a desarrollar, prototipo que implementa un set de datos de entrenamiento, y diseño de interfaces (mockups) con base en criterios de usabilidad que soporten la arquitectura propuesta; y la última, que presenta las conclusiones y el trabajo futuro.

\section{Trabajos Relacionados}

Como principio básico de funcionamiento, un sistema personalizado requiere adquirir información del usuario y usarla para realizar inferencias de las características de tipo abstracto que son utilizadas en la definición del comportamiento del sistema hacia el usuario (Ifeachor, Hu, Sun, Hudson, \& Zervakis, 2009), esto es posible mediante la definición del modelo de usuario del sistema. Un modelo de usuario permite a un sistema dar respuesta a las características que representan el conocimiento y preferencias del usuario, que el sistema asume que éste tiene (Martins, Faria, De Carvalho, \& Carrapatoso, 2008).

Hasta el momento, las áreas de desarrollo más destacadas que cuentan con sistemas personalizados que implementan modelos de usuario, son las de eLearning y eHealth. A manera de ejemplo, en el área de eLearning, González, Duque, y Ovalle (2008) presentan un sistema personalizado de educación virtual, que consta de un modelo de usuario basado en las características del estudiante que son relevantes en el proceso educativo, además de la interrelación entre ellas. Los parámetros contemplados también fueron utilizados por Feisst, dos Santos, Mitic, y Christ (2005) cuyos sistemas adaptan el contenido para que coincida con las metas y personalidades de aprendizaje, para lo cual los nodos de contenido con características comunes de aprendizaje se agrupan en clústeres de contenido desde donde el sistema ejecuta la personalización.

Desde la noción de sistemas personalizados orientados hacia eHealth, el historial médico electrónico se ha convertido en una herramienta importante para la concepción de dichos sistemas. Luo, Tang, y Thomas (2011) y Yadav y Poellabauer (2012) describen como los Registros Personales de Salud [Personal Health Records, PHR], han sido implementados en sistemas personalizados y se utilizan para recomendar aspectos de cuidado en casa, partiendo de la información consignada en dichos registros. En los últimos años se ha generado el concepto de promoción de hábitos y estilos de vida saludables, con los cuales se pretende lograr la prevención de cientos de enfermedades de preocupación mundial.

Es importante destacar también a los trabajos realizados por Meyer, Çakır-Turgut, y Helmer (2012), y Buttusi y Chittaro (2008), porque comprenden la mayoría de los conceptos de investigación contemplados en este artículo, es decir, presentan sistemas personalizados basados en modelos de usuario que estén orientados a eHealth, de manera que se promocionan
This article describes how the user model should meet the ISO / TR 14292 standard for a personalized system, to support the promotion of physical activity and a healthy diet as part of the promotion of habits and healthy lifestyles.

This article is structured as follows: the first section covers work-related factors, the second describes the conceptual framework in which this article is based and the third describes the methodology used for research; the fourth shows the results of this study, which is divided into: characterization of the user model, user model according to the ISO / TR 14292 standard, relationships and inferences from the user model, proposal of a reference architecture for the system to develop, a prototype that implements a set of training data, and interface design (mockups) based on usability criteria that support the proposed architecture; and the last one, which presents the conclusions and future work.

\section{Related work}

As a basic principle of operation, a personalized system requires acquiring user information and using it to make inferences on the characteristics of abstract type that are used in defining the behavior of the system to the user (Ifeachor, Hu, Sun, Hudson, \& Zervakis, 2009), this is possible by defining the type of system user. A user model allows a system to respond to the features that represent the knowledge and preferences of the user, the system assumes that it has (Martins Faria, De Carvalho, \& Carrapatoso, 2008).

Until now, the most important development areas that have systems that implement custom user models are eLearning and eHealth. For example, in the eLearning area, Gonzalez, Duke, and Ovalle (2008) present a personalized virtual education system, consisting of a user model based on student characteristics that are relevant in the educational process, as well the interrelationship between them. The parameters referred to were also used by Feisst, dos Santos, Mitic, and Christ (2005) whose systems adapt the content to match the goals and personalities learning, for which nodes content with common learning characteristics are grouped into content clusters where the system runs the personalization.

Since the notion of personalized systems oriented to eHealth, electronic medical records have become an important tool for designing such systems. Luo, Tang, and Thomas (2011) and Yadav and Poellabauer (2012) 
describe as the Personal Health Records theme has been implemented in personalized systems and used to recommend home care aspects, starting from the information contained in these records. In recent years, there has been promotion of the concept of habits and healthy lifestyles, with which it is intended to achieve the prevention of hundreds of diseases of global concern.

It is important to highlight the work conducted by Meyer, Çakır-Turgut and Helmer (2012), and Buttusi and Chittaro (2008), because they comprise the majority of research concepts covered in this article, ergo, they present personalized systems based user models that are oriented towards eHealth, so that habits and healthy lifestyles are promoted; however, the model is not under any standard, rule or medical reference, takes very little data and omits several that are important when making an appropriate recommendation health.

Consider also that Meyer et al., (2012) differ from this proposal, as obtained information from the user to create their model, comes from the context of this and not the inherent characteristics of user's personality. Moreover, Buttusi and Chittaro (2008) focus on habits and promoting healthy lifestyles only on physical activity that the person can make, regardless of other aspects of health promotion, such as healthy diet, which is an essential complement to physical activity.

By reviewing previous work, existing models and how these could serve the area of e-Health were identified. However, some gaps were found in them, because they do not include some features necessary for health, which are part of PHR. Based on the identification of this need, it is sought to create a generic model for health, especially for the promotion of habits and healthy lifestyles, of personalized way.

\section{Conceptual framework}

\section{A. User model}

ICT makes it possible to capture large amounts of information that can support relevant aspects of life, such as health. When this information is categorized, structured and stored to lead to personalization, it takes the name user model (Barua, Kay, Kummerfeld, \& Paris, 2011). A user model is a representation of information about an individual user. Considering its nature, a user model can deal with conceptual information about the user's knowledge, procedural knowledge, interests, immediate purpose, background and individual traits. In- hábitos y estilos de vida saludables; sin embargo, el modelo no se encuentra conforme a ningún estándar, norma o referencia médica, toma muy pocos datos y omite varios que son importantes al momento de hacer una recomendación adecuada de salud.

Hay que considerar también que Meyer et al., (2012) difieren de esta propuesta, en que la información que se obtiene del usuario para crear su modelo, proviene del contexto de éste y no de las características inherentes a su personalidad. Por otro lado Buttusi y Chittaro (2008) centran la promoción de hábitos y estilos de vida saludables únicamente en la actividad física que puede hacer la persona, sin tener en cuenta los demás aspectos de la promoción en salud, tales como la dieta saludable, que es un complemento esencial a la actividad física.

Por medio de la revisión de los anteriores trabajos se identificaron los modelos existentes y la manera en que ellos podrían servir al área de e-Health. Sin embargo, se encontraron ciertas brechas en ellos, porque no tienen en cuenta algunas características necesarias para salud, que son parte del PHR; Con base en la identificación de esta necesidad, se busca crear un modelo genérico para salud, específicamente para la promoción de hábitos y estilos de vida saludables, de manera personalizada.

\section{Marco conceptual}

\section{A. Modelo de usuario}

Las TIC hacen posible la captura de grandes cantidades de información que pueden apoyar aspectos relevantes de la vida, como la salud. Cuando esta información es categorizada, estructurada y almacenada para conducirla a una personalización, toma el nombre de modelo de usuario (Barua, Kay, Kummerfeld, \& Paris, 2011). Un modelo de usuario es una representación de la información acerca de un usuario individual. Considerando la naturaleza, un modelo de usuario puede tratar con información acerca del conocimiento conceptual del usuario, conocimiento procedimental, intereses, propósito inmediato, antecedentes y rasgos individuales. La información acerca del conocimiento puede estructurarse en modelos que utilizan valores cuantitativos y cualitativos (Buttusi, 2008).

\section{B. Sistemas personalizados}

La continua evolución de los sistemas software ha traído como consecuencia la existencia de sistemas que son cada vez más versátiles, flexibles, dependientes, recuperables, configurables y personalizables, por medio de la adaptación a ambientes y características cambiantes (Brun, 2009). De la evolución de los sistemas software se introducen los sistemas personalizados, que son aquellos que ofrecen un ambiente único para un usuario específico, donde el usuario es la unidad esencial en el desempeño del sistema, es decir, el sistema está basado en características del usuario y en la información que él genera (González et al., 2008; Feisst et al., 2005). Este tipo de sistemas son capaces de ajustarse con base en las características del usuario, generando cambios en los contenidos y la forma en la que se presentan dichos contenidos; este tipo de sistemas tiene 
la capacidad de adaptarse de manera dinámica, a medida que la interacción entre el usuario y el sistema aumenta (Weibelzahl, 2011).

\section{Personal Health Record}

Un PHR es un repositorio usado por los pacientes para representar y gestionar su información de salud en un ambiente privado, seguro y confidencial. Los PHR son manejados por los pacientes y pueden incluir información de una gran variedad de fuentes, tanto de proveedores de servicios de salud, como de sí mismo (What is a..., 2013). En este artículo se siguen las recomendaciones de la norma ISO/TR 14292 (ISO, 2012) que soporta la definición del modelo de usuario. La norma define un conjunto de características que tienen los PHR, algunos de los cuales serán utilizados para caracterizar el modelo de usuario.

\section{Promoción de actividad física y dieta saludable}

La Organización Mundial de la Salud [OMS] define los hábitos y estilos de vida saludables como la percepción que un individuo tiene de su lugar, tanto en la existencia, como en el contexto de la cultura y del sistema de valores en los que vive, y en relación con sus objetivos, expectativas, normas e inquietudes (OMS, 2012). Los estilos de vida están determinados por procesos sociales, tradiciones, hábitos, conductas y comportamientos de los individuos y grupos de población, que conllevan a la satisfacción de las necesidades humanas, para alcanzar la calidad de vida (Uniminuto, 2014).

Desde el punto de vista personal-individual, se consideran como hábitos y estilos de vida saludables: el auto-cuidado; el control de factores de riesgo como obesidad, sedentarismo, tabaquismo, alcoholismo y de algunas patologías como la hipertensión y la diabetes, por medio de una dieta saludable; y la realización de actividades en tiempo libre y disfrute del ocio a través de la actividad física.

\section{Descripción de la metodología}

En el desarrollo del presente trabajo se usó la metodología de investigación para ingeniería. Siguiendo esta metodología, a través de sus etapas, como muestra la Figura 1, primero se obtiene, por medio de una revisión sistemática, una base conceptual, y se generan fichas de resumen para la comprensión lectora; en seguida, se utiliza la metodología Delphi (Carreño, 2009) para realizar la selección de ítems del modelo de usuario conforme con las recomendaciones de la norma ISO/TR 14292, por medio de recolección de datos, la preparación de tablas de comparación y la realización de reuniones con expertos en las áreas involucradas en el proyecto.

En la parte de desarrollo del sistema, la metodología utilizada es Diseño Centrado en el Usuario [DCU], la cual esta soportada en la norma ISO 9241-210 (ISO, 2010); Asimismo, para considerar la evaluación completa del proyecto, se utiliza la metodología DESMET, que permite la evaluación de la calidad del producto a entregar.

Siguiendo las metodologías descritas, inicialmente, a partir de la metodología Delphi, se realizó la caracterización del mo- formation about the knowledge can be structured models using quantitative and qualitative values (Buttusi, 2008).

\section{B. Personalized systems}

The continuing evolution of software systems has resulted in the existence of systems that are becoming more versatile, flexible, dependent, recoverable, configurable and personalizable, through adaptation to changing environments and characteristics (Brun, 2009). From evolution of software systems the personalized systems are introduced, which are those that offer a unique environment for a specific user, where the user is the essential unit system performance, ergo, the system is based on user characteristics and information that he or she have generates (Gonzalez et al., 2008;. Feisst et al., 2005). Such systems are able to adjust based on user characteristics, leading to changes in the content and the way in which these contents are presented; these kind of systems have the ability to adapt dynamically, as the interaction between the user and the system increases (Weibelzahl, 2011).

\section{Personal Health Record}

A PHR is a repository used by patients to represent and manage your health information in a private, safe and confidential environment. PHRs are managed by patients and can include information from a variety of sources, both health service providers, as himself (What is a ..., 2013). In this article the recommendations of the ISO / TR 14292 (ISO 2012) standard that supports the definition of user model are followed. The standard defines a set of features that have the PHR, some of which will be used to characterize the user model.

\section{Physical activity and healthy diet promotion}

The World Health Organization [WHO] defines the habits and healthy lifestyles as the perception that an individual has his place in existence, in the context of culture and value system in which he or she live and in relation its objectives, expectations, rules, concerns (WHO, 2012). Lifestyles are determined by social processes, traditions, habits, conduct and behavior of individuals and population groups, leading to the satisfaction of human needs, to achieve the quality of life (Uniminuto, 2014).

From a personal-individual point of view, they are considered habits and healthy lifestyles: self-care; control of risk factors such as obesity, sedentary lifestyle, smoking, alcoholism and certain diseases such as hyperten- 
sion and diabetes, through a healthy diet; and performing leisure activities and enjoy entertainment through physical activity.

\section{Methodological description}

In undertaking this work the research methodology for engineering was used. Following this methodology, through its stages, as shown in FIGURE 1, first obtained by means of a systematic review, a conceptual basis, and summary sheets for reading comprehension are generated; then, the Delphi (Carreño, 2009) methodology is used to make the selection of items from the user model line with the recommendations of ISO / TR 14292 standard, through data collection, preparation and comparison tables and holding meetings with experts in the areas involved in the project.

During system development, the methodology used is User Centered Design [DCU], which is supported in ISO 9241-210 (ISO, 2010). Also, to consider the complete evaluation of the project, the DESMET methodology is used to evaluate the quality of the product to be delivered.

Following the methodologies described, initially, from the Delphi methodology, the characterization of the user model was performed in order to identify the most significant items to include in the personalized system; such items were compared, assessed and defined, so that, in accordance with the ISO / TR 14292 standard, they are considered within the model to perform accurate and successful recommendations that satisfy the user; finally, a selection of technologies is implemented a personalized system in accordance with the proposed user model. Based on the selected technologies, reference architecture for personalized systems in promoting physical activity and healthy diet based on a user model in accordance with ISO / TR 14292 standard is suggested.

\section{User model generation and application}

\section{A. User model characterization}

According to Martins et al., (2008) performing the characterization of the user model begins with a generic profile, a psychological profile and other features. Consistent with the DCU methodology, they are considered characteristic elements classified as shown in TABLE $\mathbf{1}$.

Based on the information contained in TABLE $\mathbf{1}$ and
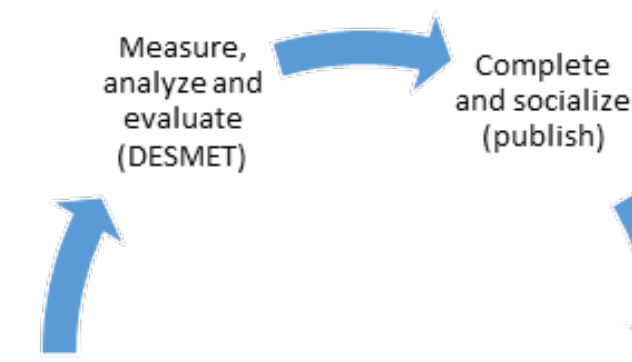

Build and

Develop

(UCD-Delphi)

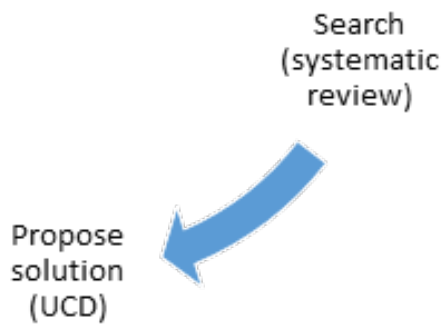

Figure 1. Stages of research methodology for engineering / Etapas de la metodología de investigación para ingeniería

delo de usuario, con el fin de identificar los ítems más significativos a incluir en el sistema personalizado; tales ítems fueron comparados, evaluados y definidos, para que, de conformidad con el estándar ISO/TR 14292, sean considerados dentro del modelo para realizar recomendaciones acertadas y exitosas que satisfagan al usuario; por último, se hace una selección de tecnologías para implementar el sistema personalizado de conformidad con el modelo de usuario propuesto. Con base en las tecnologías seleccionadas, se sugiere una arquitectura de referencia para sistemas personalizados en promoción de actividad física y dieta saludable basados en un modelo de usuario conforme con la norma ISO/TR 14292.

\section{Generación y aplicación del modelo de usuario}

\section{A. Caracterización del modelo de usuario}

De acuerdo con Martins et al., (2008) se empieza a realizar la caracterización del modelo de usuario a partir de un perfil genérico, un perfil psicológico y otras características. De manera consistente con la metodología DCU, son considerados los elementos característicos clasificados que muestran la TABLA 1.

Partiendo de la información contenida en la Tabla 1 y usando la metodología Delphi, se crean las tablas de comparación (x vs. y) para definir, de manera preliminar, las relaciones entre cada uno de los elementos característicos considerados. Para ello, hay que consignar tales elementos o ítems en los ejes de la tabla con el fin de determinar dependencias o independencias entre ítems. Es pertinente resaltar que, aunque todos los ítems que debe tener el modelo de usuario que conducen personalización fueron considerados, a través de la metodología Delphi se pretende obtener, como primer resultado, únicamente aquellos que se deben solicitar al usuario en el momento de su registro en el sistema.

Entonces, para cada una de las clasificaciones de ítems con- 
Table 1. User model characterization / Caracterización del modelo de usuario

\begin{tabular}{|c|c|c|}
\hline \multirow[t]{3}{*}{ Generic profile / Perfil genérico } & $\begin{array}{l}\text { Generic information / Información } \\
\text { genérica }\end{array}$ & $\begin{array}{l}\text { Complete name / Nombre completo } \\
\text { E - mail / Correo electrónico } \\
\text { Telephone number / Teléfono } \\
\text { Height / Estatura } \\
\text { Weight / Peso } \\
\text { Body Mass Index / Índice Masa Corporal } \\
\text { ID number / Número de identidad }\end{array}$ \\
\hline & $\begin{array}{l}\text { Demographic information / } \\
\text { Información demográfica }\end{array}$ & $\begin{array}{l}\text { Birthdate / Fecha de nacimiento } \\
\text { Gender / Género } \\
\text { Ethnicity / Etnia } \\
\text { Marital status / Estado civil } \\
\text { Place of birth / Lugar de nacimiento } \\
\text { Academic level / Nivel académico } \\
\text { Occupation / Ocupación } \\
\text { Age / Edad } \\
\text { Place of residence / Lugar de residencia }\end{array}$ \\
\hline & $\begin{array}{l}\text { Physical limitations / Limitaciones } \\
\text { fisicas }\end{array}$ & $\begin{array}{l}\text { Auditory type / De tipo auditivo } \\
\text { Visual type / De tipo visual } \\
\text { Neurological / De tipo neurológico } \\
\text { Type of motor / De tipo motriz }\end{array}$ \\
\hline \multirow[t]{3}{*}{$\begin{array}{l}\text { Psychological profile / Perfil } \\
\text { sicológico }\end{array}$} & Habits / Hábitos & $\begin{array}{l}\text { Order of your day / Orden de su día } \\
\text { Likes / Gustos } \\
\text { Abilities / Aptitudes } \\
\text { Interests / Intereses } \\
\text { Hobbies / Hobbies } \\
\text { Eating habits / Hábitos alimenticios } \\
\text { Physical activity / Actividad fisica } \\
\text { Vices / Vicios } \\
\text { Things you do not like / Cosas que no le gustan } \\
\text { Vacation time / Tiempo de vacaciones } \\
\text { Working hours / Horas laborales } \\
\text { Family hours / Horas familiares }\end{array}$ \\
\hline & Beliefs / Creencias & $\begin{array}{l}\text { Politic ideology / Ideología politica } \\
\text { Religious ideology / Ideología religiosa } \\
\text { Values / Valores }\end{array}$ \\
\hline & Others / Otros & $\begin{array}{l}\text { Learning style / Estilo de aprendizaje } \\
\text { Personality traits / Trazos de personalidad } \\
\text { Small autobiography / Pequeña autobiografia } \\
\text { Phobias / Fobias }\end{array}$ \\
\hline \multirow[t]{2}{*}{$\begin{array}{l}\text { Other features / Otras caracte- } \\
\text { risticas }\end{array}$} & User goals / Objetivos del usuario & $\begin{array}{l}\text { Acceptable average activity / Promedio aceptable de actividad fisica } \\
\text { Balance diet / Dieta balanceada }\end{array}$ \\
\hline & Others / Otros & $\begin{array}{l}\text { Socioeconomic / Estrato socioeconómico } \\
\text { Navigational records / Registros de navegación } \\
\text { Access devices / Dispositivos de acceso } \\
\text { Languages / Idiomas } \\
\text { Family life / Convivencia familiar } \\
\text { Acquired knowledge / Conocimiento adquirido } \\
\text { Account creation / Creación de cuenta }\end{array}$ \\
\hline
\end{tabular}

templadas en la TABLA I, se hizo su propia tabla comparativa, así mismo con cada perfil descrito, y por último, entre todos los elementos que resultaron de la primera parte de la caracterización. La Figura 2 muestra una de las tablas comparativas creadas, ésta corresponde a la clasificación de información demográfica del perfil genérico, donde se evidencian las relaciones de dependencia e independencia entre los ítems. using the Delphi methodology, comparison tables (x vs. y) are created to define, in a preliminary way, the relationship between each of the characteristic elements considered. To do this, we must consign such elements or items in the axes of the table in order to determine dependency or independence between items. It is perti- 


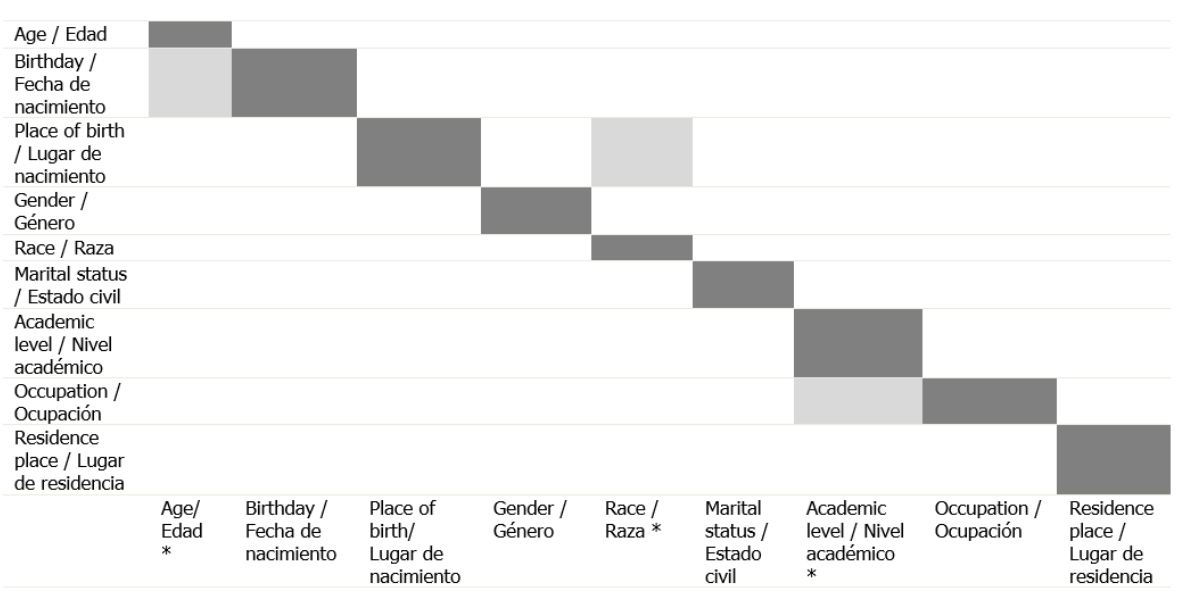

Figure 2. Comparison of demographic information / Comparación de información demográfica

nent to note that, although the user's model considered all the items that lead personalization, through the Delphi methodology, we aimed, as a first result, only those that should be asked to the user at the time of registration in the system.

Then, its own comparative table was prepares for each classification of items listed in TABLE $\mathbf{I}$; the same was done for each profile described, as between all the elements that resulted from the first part of the characterization. Figure 2 shows one of the comparative tables created, corresponding to the classification of generic demographic profile, where relationships of dependence and independence between items are evident.

Once these tables are created, it is necessary to choose the required items to enable the user to capture, manage, classify, store and drive personalization of interventions. So, it is necessary to define a list of metrics that help select the items to ask the user; such metrics are presented in TABLE 2.

The relationship of the metrics to each other is important, since the items that are independent are only assigned a value of one, so it is essential to ask the user for these elements. Conversely, if the item is dependent, continue with the classification below in TABLE 2, i.e., defining whether the relationship between dependent items is quantitative or qualitative, that is, dependent upon an exact relationship - like a formulation - or if the value is inferable from hypotheses that arise from experience.

Non-dependence or interdependence to each other is revealed based on the comparative tables created, then there is no mutual dependency when the inference of elements occurs only in one direction of the relations-
Table 2. List of metrics for items selection / Lista de métricas para selección de ítems

\begin{tabular}{lll}
\hline & Metrics / Métricas & $\begin{array}{l}\text { Value / } \\
\text { Valor }\end{array}$ \\
\hline 1 & Independence / Independencia & 1 \\
\hline \multicolumn{2}{l}{ Dependence / Dependencia } & 0 \\
\hline $\begin{array}{l}\text { Quantitative relationship / Relación } \\
\text { cuantitativa }\end{array}$ & 0,5 \\
\hline $\begin{array}{l}\text { Qualitative relationship / Relación } \\
\text { cualitativa }\end{array}$ & 0,5 \\
\hline $\begin{array}{l}\text { No mutual dependency / No dependencia } \\
\text { mutua }\end{array}$ & 0,7 \\
\hline Mutual dependency / Dependencia mutua & 0,3 \\
\hline 4 & Periodicity / Periodicidad & 0,8 \\
\hline No periodicity / No periodicidad & 0,2 \\
\hline Consistency / Consistencia & 0 a l \\
\hline \hline
\end{tabular}

Una vez obtenidas estas tablas, es necesario escoger los ítems requeridos que proporcione el usuario para capturarlos, gestionarlos, clasificarlos, almacenarlos y conducir a la personalización de las intervenciones. Así pues, hay que definir una lista de métricas que ayudan a seleccionar los elementos que se deben solicitar al usuario; tales métricas se presentan en la TABLA 2.

Es importante resaltar la relación de las métricas entre sí, puesto que los ítems que resulten independientes solo tienen asignado el valor de uno, por lo que es imprescindible preguntar por estos elementos al usuario. Por el contrario, si el ítem resulta dependiente, se continúa con la clasificación que sigue en la TABLA 2, es decir, hay que definir si la relación entre ítems dependientes es cuantitativa o cualitativa, esto es, si depende de una relación exacta - como una fórmula- o si el valor es inferible a partir de hipótesis planteadas que surgen de la experiencia.

La no dependencia o dependencia mutua es revelada partiendo de las tablas comparativas que fueron creadas, entonces no existe dependencia mutua cuando la inferencia de elementos se da solo en una dirección de la relación y, en consecuencia, existirá la dependencia mutua cuando un ítem sea deducible a partir de otro, en ambos sentidos de la relación. Las métri- 
Table 3. Consolidated items according to the evaluation metrics / Consolidado de ítems de acuerdo con las métricas de evaluación

\begin{tabular}{ll}
\hline \hline Metrics / Métricas & Value / Valor \\
\hline Total items / Total ítems & 48 \\
\hline \multicolumn{1}{|l}{ Items' generic profile / Ítems perfil genérico } & 20 \\
$\begin{array}{l}\text { Items' psychological profile / Ítems perfil } \\
\text { psicológico }\end{array}$ & 19 \\
$\begin{array}{l}\text { Items' other features / Ítems otras características } \\
\text { Independent items / Ítems independientes }\end{array}$ & 9 \\
\hline $\begin{array}{l}\text { Dependent items / Ítems dependientes } \\
\text { Items not mutually dependent / Ítems no }\end{array}$ & 13 \\
$\begin{array}{l}\text { mutuamente dependientes } \\
\text { Items mutually dependent / Ítems mutuamente } \\
\text { dependientes }\end{array}$ & 24 \\
\hline $\begin{array}{l}\text { Periodical items / Ítems periódicos } \\
\text { No periodical items / Ítems no periódicos }\end{array}$ & 13 \\
\hline
\end{tabular}

cas que se observan en la TABLA 3 surgen de la dependencia mutua; lo que significa que las métricas de periodicidad o no periodicidad y consistencia puede garantizar una probabilidad más alta de acertada inferencia entre ítems. De esta manera, el proceso de evaluación de los ítems, por medio de las métricas, brinda los resultados mostrados en la TABLA 3, el número indica la cantidad de ítems para ser registrados en el perfil genérico, psicológico y otras características.

A partir de las métricas definidas, cuyos valores fueron asignados a cada ítem con un valor sumado final, se tiene un preliminar de elementos seleccionados para el modelo de usuario. Las razones por las cuales se escogen los ítems de acuerdo con el valor total son: por su calidad de ítems independientes; para los ítems dependientes, que cumplan con las métricas tres y cuatro; los ítems dependientes son periódicos; los ítems dependientes que tengan consistencia igual o mayor a 0,6. La TABLA 4 presenta la lista de ítems preliminares seleccionados para el modelo de usuario.

Los ítems de la TABLA 4 marcados con asterisco $\left(^{*}\right)$ son los independientes; los escritos en cursiva cumplen con la razón dos y, al mismo tiempo, con la razón tres o cuatro; esto es así por la explicación dada en la descripción de las métricas. Se obtiene un total de 26 ítems.

\section{B. Modelo de usuario conforme a la norma ISO/TR 14292}

Los resultados a mostrar en esta sección dependen, en primer lugar, de las caracterizaciones de la norma ISO/TR 14292, la cual trata acerca de los PHR. En la primera caracterización se observan los temas que abarca este reporte técnico, el cual realiza una clasificación de los registros de salud personal de acuerdo con seis dimensiones, las cuales tienen un orden específico de opciones. Las dimensiones abarcadas se clasifican dentro de los temas: estructura del PHR, orden y parámetros, seguridad, comunicación y arquitectura. Para propósitos de este trabajo, en esta sección son utilizados los temas de estructura, orden y parámetros, que corresponden a la dimensión uno de la norma, la cual es referenciada como PHR.1: Alcance hip and, consequently, there will be mutual dependence when an item is deductible from another, in both senses of the relationship. The metrics that are observed in TABle 3 arise from the mutual dependency; meaning that metrics periodicity or frequency and consistency can guarantee a higher probability of successful inference between items. Thus, the evaluation process of the items, through metrics, provides the results shown in $\mathbf{T A}_{\mathbf{A}}-$ BLE 3; the number indicates the number of items to be registered in the generic, psychological profile and other features.

From the metrics defined, whose values were assigned to each item with a final added value, is obtained a preliminary list of selected items for the user's model. The reasons why the items according to the total value are chosen are: for quality independent items; for dependent items, that meet three and four metrics; dependent items are periodicals; dependent items that have consistency equal to or greater than 0.6. Table 4 presents the preliminary list of items selected for the user model.

Items in TABLE 4 marked with an asterisk $\left(^{*}\right)$ are independent; italicized items meet reason two and, at the same time, reason three or four; this is the explanation given in the description of the metrics. A total of 26 items is obtained.

\section{B. User Model to ISO / TR 14292 standard}

The results displayed in this section depend, first, on the characterizations of the ISO / TR 14292 standards, which is about the PHR. In the first characterization topics covered in this technical report, which makes a classification of personal health records according to six dimensions, have a specific order of options. The dimensions covered are classified within the subjects: PHR structure, command and parameters, security, communication and architecture. For the purposes of this paper, this section uses topics of structure, order and parameters, which correspond to dimension one of the standard, which is referenced as PHR.1: Scope of information. TABLE 5 demonstrates the order of the structure and parameters of the PHR.

Because the issue of PHR involves very specific aspects in the field of health, an expert was consulted in that area to find out: which items cannot be excluded of records; which ones items affect significantly people's health and behavior; and which ones are optional. PHR parameters are filled with the characteristic elements 
Table 4. Preliminary user model items / Ítems preliminares del modelo de usuario

\begin{tabular}{|c|c|c|}
\hline \multirow[t]{3}{*}{ Generic profile / Perfil genérico } & $\begin{array}{l}\text { Generic information / Información } \\
\text { genérica }\end{array}$ & $\begin{array}{l}\text { Complete name* / Nombre completo* } \\
\text { E- mail* / Correo electrónico* } \\
\text { Telephone number* / Teléfono* } \\
\text { height }^{*} \text { / Estatura* } \\
\text { Weight* / Peso* } \\
\text { ID number* / Número de identidad* }\end{array}$ \\
\hline & $\begin{array}{l}\text { Demographic information / } \\
\text { Información demográfica }\end{array}$ & $\begin{array}{l}\text { Birth date* / Fecha de nacimiento* } \\
\text { Gender* / Género* } \\
\text { Ethnicity / Etnia } \\
\text { Marital status* / Estado civil* } \\
\text { Occupation / Ocupación }\end{array}$ \\
\hline & $\begin{array}{l}\text { Physical limitations / Limitaciones } \\
\text { fisicas }\end{array}$ & $\begin{array}{l}\text { Auditory type* / De tipo auditioo* } \\
\text { Visual type* / De tipo visual } \\
\text { Neurological }\end{array}$ \\
\hline \multirow[t]{2}{*}{$\begin{array}{l}\text { Psychological profile / Perfil } \\
\text { sicológico }\end{array}$} & Habits / Hábitos & $\begin{array}{l}\text { Order of your day / Orden de su dia } \\
\text { Likes / Gustos } \\
\text { Interests / Intereses } \\
\text { Hobbies / Hobbies } \\
\text { Eating habits / Hábitos alimenticios } \\
\text { Physical activity / Actividad fisica } \\
\text { Vices / Vicios } \\
\text { Things you do not like / Cosas que no le gustan } \\
\text { Working hours / Horas laborales }\end{array}$ \\
\hline & Others / Otros & Personality traits / Trazos de personalidad \\
\hline Other features / Otras características & Others / Otros & $\begin{array}{l}\text { Socioeconomic stratum* / Estrato socioeconómico* } \\
\text { Family life / Convivencia familiar }\end{array}$ \\
\hline
\end{tabular}

concerning each part of the structure and this is the second characterization of the standard.

To ensure the preliminary result of user model - presented model in paragraph A of this section - is compliant with the ISO / TR 14292 standard, this process is divided into two parts: the first consists of a junction between the items user model and those obtained from the second characterization of the standard. Therefore, table storage is created, in a column, of the model items, and other items of the standard, against one another, looking for matches. This exercise results in 29 items. Using the methodology DCU, the second part of this process is categorized into four groups and divides the resulting items, representing how to obtain user data. This process was advised by experts in the various areas of knowledge, including: a psychologist, a physical educator, a nutritionist, a physiotherapist and a health professional. Figure 3 shows the recorded thoughts, considering that the final objective is promotion of physical activity and a healthy diet.

As this work has as a main purpose to generate adhesion (retention of users) to a personalized system based on a user model, according to a standard of personal health records to deliver recommendations to promote
Table 5. PHR structure, order and parameters / Estructura, orden y parámetros del PHR

\begin{tabular}{ll}
\hline Gode / Código & Description / Descripción \\
\hline PHR.1.A & $\begin{array}{l}\text { Wide range of health issues / Amplio rango de } \\
\text { temas de salud. }\end{array}$ \\
\hline PHR.1.B & $\begin{array}{l}\text { Information about personal contacts / Infor- } \\
\text { mación acerca de contactos personales. }\end{array}$ \\
\hline PHR.1.G & $\begin{array}{l}\text { The subject of the record interactions with } \\
\text { caregivers / Interacciones del sujeto del registro con } \\
\text { cuidadores. }\end{array}$ \\
\hline PHR.1.D & $\begin{array}{l}\text { Copies and registration of health care } \\
\text { information / Copias y registro de información del } \\
\text { cuidado de salud. }\end{array}$ \\
\hline PHR.1.E & $\begin{array}{l}\text { Specific care teams / Equipos de cuidados } \\
\text { específicos. }\end{array}$ \\
\hline PHR.1.F & $\begin{array}{l}\text { Lifestyle information / Información del estilo de } \\
\text { vida. }\end{array}$ \\
\hline PHR.1.G & $\begin{array}{l}\text { Handling a particular clinical condition / } \\
\text { Manejo de una condición clínica particular. }\end{array}$ \\
\hline
\end{tabular}

de la información. La TABLA 5 evidencia el orden de la estructura del PHR y sus parámetros.

Debido a que el tema de PHR involucra aspectos muy específicos en el dominio de la salud, se consultó a una persona experta en esa área para saber qué ítems no se pueden excluir del registro, cuáles afectan considerablemente la salud de las personas y su comportamiento, y cuáles son opcionales. Los 


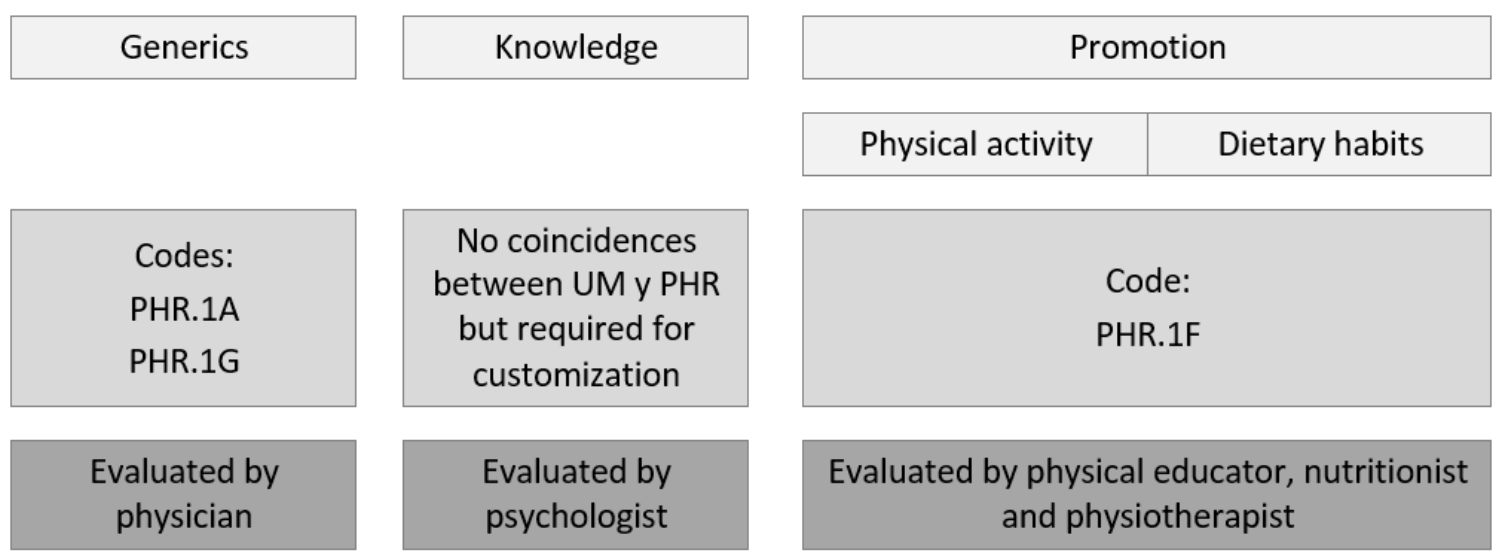

Figure 3. Items structure user model / Estructura de ítems modelo de usuario

parámetros del PHR se llenan con los elementos característicos concernientes a cada parte de la estructura y esto constituye la segunda caracterización de la norma.

Para lograr que el resultado preliminar del modelo de usuario - presentado en el apartado A de esta sección esté conforme con la norma ISO/TR 14292, este proceso se divide en dos partes: la primera consta de un cruce de ítems entre los del modelo de usuario y aquellos obtenidos de la segunda caracterización de la norma. Por lo tanto, se crea una tabla que consigna, en una columna, los ítems del modelo, y en otra, los ítems de la norma, comparándolos entre sí, buscando coincidencias. Este ejercicio da cuenta de 29 ítems resultantes. Utilizando la metodología DCU, la segunda parte de este proceso consiste en categorizar y dividir en cuatro grupos los ítems resultantes, lo que representa la manera de obtener los datos del usuario. En este proceso se contó con la asesoría de expertos en las diversas áreas del conocimiento, entre ellos: un psicólogo, un educador físico, un nutricionista, un fisioterapeuta y un profesional de la salud. La Figura 3 muestra la idea consignada, teniendo en cuenta que el objetivo final del trabajo es la promoción de la actividad física y la dieta saludable.

Ya que este trabajo tiene como principal fin generar adherencia (retención de los usuarios) a un sistema personalizado basado en un modelo de usuario, conforme a una norma de registros de salud personales que entrega recomendaciones para promocionar la actividad física y la dieta saludable, las recomendaciones son evaluadas por profesionales de la salud, expertos en las líneas de intervención que aborda este artículo.

De la Figura 3 hay que resaltar varios puntos:

- Los códigos se escogen de acuerdo con los ítems seleccionados, debido a que el ISO/TR 14292 es solo una recomendación y una guía. Los códigos escogidos son:

PHR.1.A Amplio rango de temas de salud, entre los cuales se incluye reconocer al usuario en forma general y con algunos ítems que permiten una primera impresión diagnóstica.

PHR.1.F Información del estilo de vida, que incluye estado físico, ejercicio, nutrición, dieta y horas de sueño, entre otros. physical activity and healthy diet, recommendations are assessed by health professionals, experts in the areas of intervention that approach this article.

Regarding Figure 3, several points should be highlighted:

- The codes will be chosen according to the selected items, because the ISO / TR 14292 is only a recommendation and guidance. The following codes have been chosen:

PHR.1.A Wide range of health issues, including recognizing the user is included in general and with some items that allow a first diagnostic impression.

PHR.1.F Info lifestyle, which includes fitness, exercise, nutrition, diet and sleep, among others.

PHR.1.G Handling a particular clinical condition, this allows the user to recognize information that could lead to a correct personalization.

- A and $\mathrm{G}$ codes are grouped by affinity on the subject. The $\mathrm{F}$ code provides information about the purpose of work, so it is considered separately, as important.

- During the first part of the process in accordance with the standard, some user model items are no coincidences with the recommendations of the PHR. However, due to the metrics evaluated and the results of these, they should be included in this second part because, as noted, are important to drive personalization.

- Each of the categories considered offers evaluation and recommendation by people with advanced knowledge in these areas. Then the items are categorized as presented in Figure 4. 


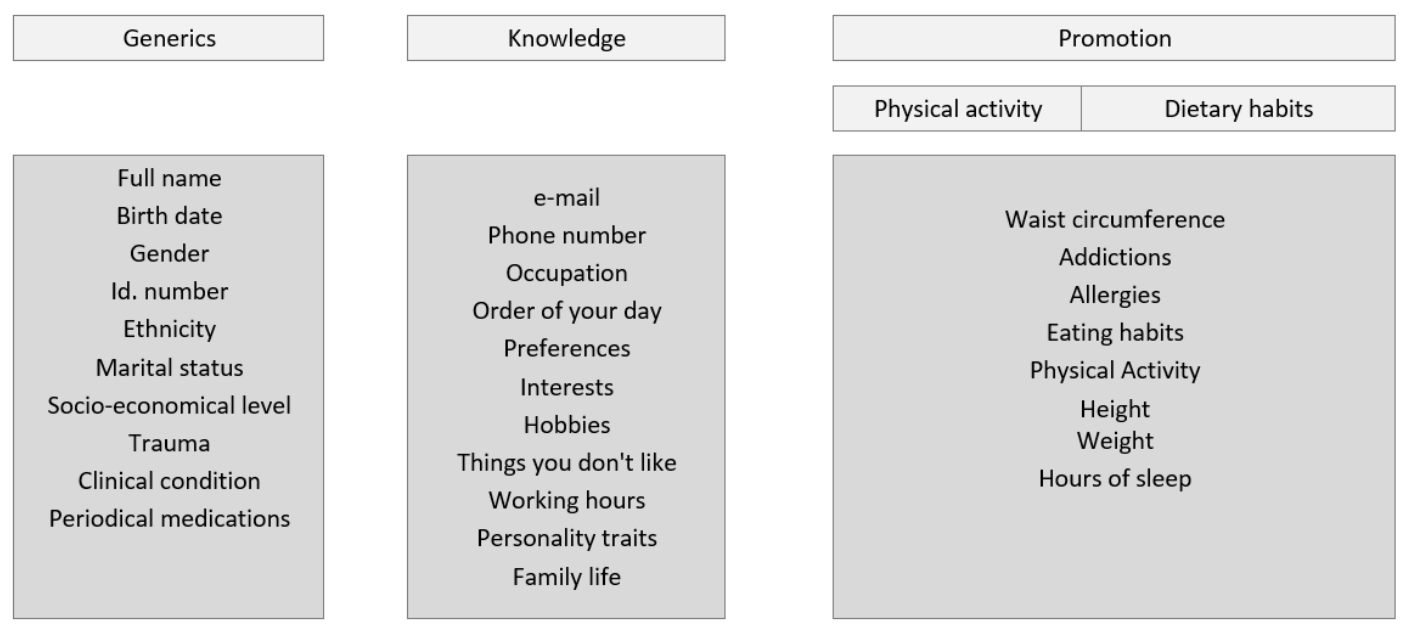

Figure 4. Items resulting from the process in accordance with ISO / Items resultantes del proceso de conformidad con la norma ISO

\section{User model relations and inferences}

This third section comprises the user model intelligent agent, necessary to lead to a personalization according to the information provided from categorized items. As a first step, the relationship between the items in a table of relationships as a basis for learning of model agent is structured, i.e., the relationship table becomes, for the model, in the way it should learn and execute processes of inference; relationships between items are made from the comparative tables of information and respecting the metrics proposed in TABLE 2 .

Once the necessary user data are obtained and the intelligent agent establishes the form of learning, with help of a classification algorithm it can make the inference process determine the physical activity intervention and proper healthy diet for the user according to their status, needs and interests. The Figure 5 is an example of inference coming from the user's birth date.

It is shown in Figure 5 that the user's age can be inferred from the comparison between the current system date and date of birth of the user; with this information the recommendation of an intervention under the condition makes it better fit the user. An important consideration evidenced in the flowchart is that, while taking into account the information provided by the user through the system containing the model, the intelligent agent obtains additional information from user interaction with the system, from checkpoints established, such as the fact of seeing if the user like or does not like the inferred and recommended recommendation. This additional information will allow the intelligent agent to feed back better and deepens their relations - getting, as
PHR.1.G Manejo de una condición clínica particular, que permite reconocer en el usuario más información que pueda conducir a una correcta personalización.

- Se agrupan los códigos A y G por la afinidad en el tema. El código $\mathrm{F}$ brinda la información acerca del objetivo del trabajo, por lo que se considera aparte, importante.

- Durante la primera parte del proceso de conformidad a la norma, algunos ítems del modelo de usuario resultan sin coincidencias con las recomendaciones del PHR. Sin embargo, debido a las métricas evaluadas y al resultado de estas, se deben incluir en esta segunda parte pues, como ya se dijo, son importantes para conducir personalización.

- Cada uno de las categorías consideradas se pone a evaluación y recomendación por parte de personas con conocimientos avanzados en dichas áreas. Entonces, los ítems categorizados quedan como lo presenta la Figura 4.

\section{Relaciones e inferencias del modelo de usuario}

Este tercer apartado comprende el agente inteligente del modelo de usuario, agente necesario para conducir a una personalización de acuerdo con la información entregada de los ítems ya categorizados. Como primera medida, se estructura la relación que existe entre los ítems en una tabla de relaciones que servirá de base de aprendizaje del agente del modelo, es decir, la tabla de relaciones se convierte, para el modelo, en la forma en la que debe aprender y ejecutar sus procesos de inferencia; las relaciones entre los ítems se realizan a partir de las tablas comparativas de información y respetando las métricas propuestas en la TABLA 2.

Una vez los datos necesarios del usuario son obtenidos y el agente inteligente establece la forma de aprendizaje, con la ayuda de un algoritmo de clasificación se puede realizar el proceso de inferencia para determinar cuál es la intervención de actividad física y dieta saludable más adecuada para el usuario, de acuerdo con su estado, necesidades e intereses. En la FigurA 


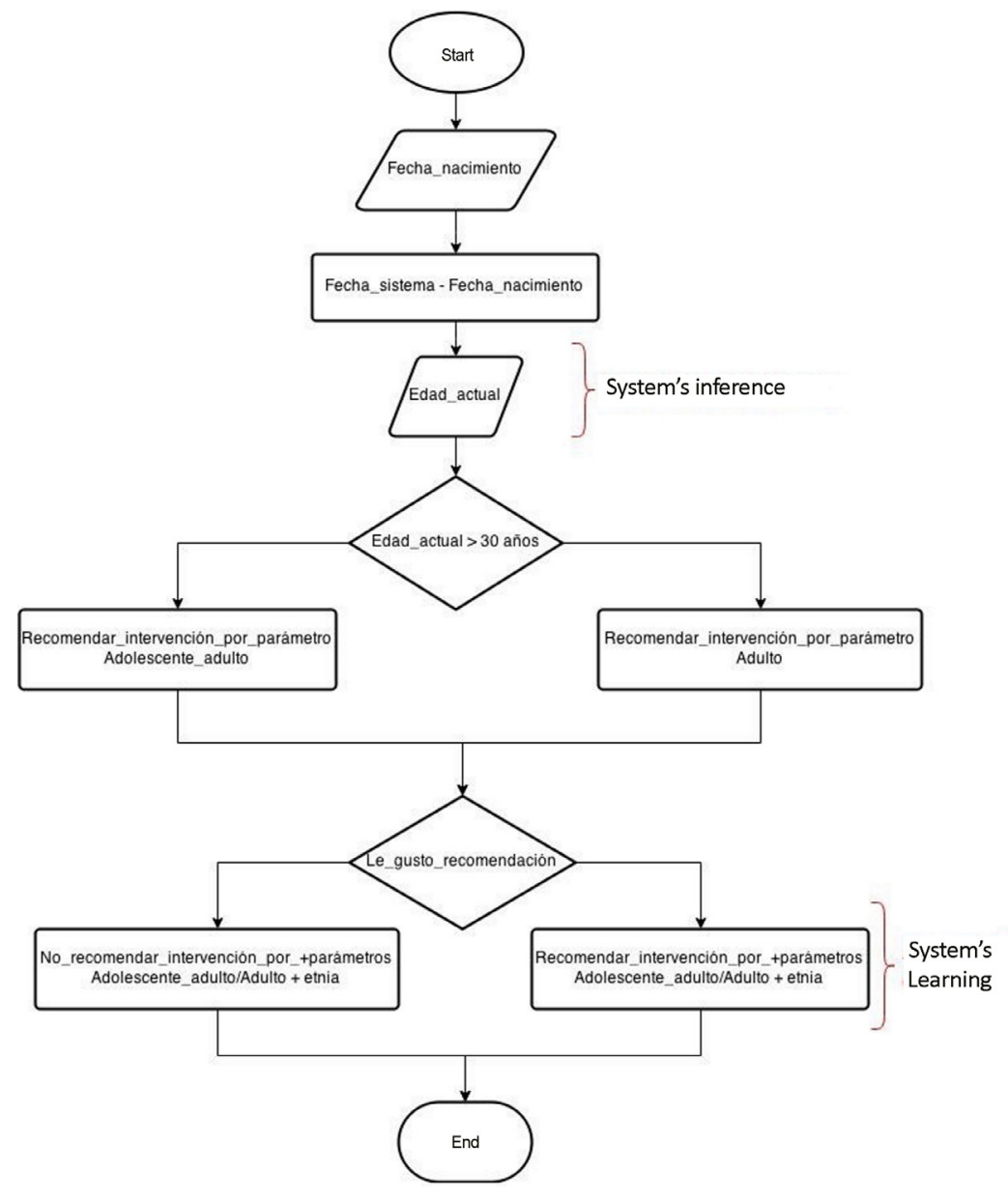

Figure 5. Flowchart intelligent agent item Date_of_Birth / Diagrama de flujo de agente inteligente ítem Fecha_nacimiento.

5 se presenta un ejemplo de inferencia a partir de la fecha de nacimiento del usuario.

Se aprecia en la Figura 5 que la edad del usuario se puede inferir a partir de la comparación entre la fecha actual del sistema y la fecha de nacimiento del usuario, con este dato se realiza la recomendación de una intervención de acuerdo con la condición que mejor se ajuste al usuario. Una consideración importante evidenciada en el diagrama de flujo es que, además de tener en cuenta la información que brinda el usuario mediante el sistema que contiene el modelo, el agente inteligente obtiene información adicional de la interacción del usuario con el sistema, a partir de puntos de control establecidos, como el hecho de contemplar si al usuario le gusta o no la recomendación inferida y recomendada. Se consigna dentro del modelo esta información adicional que le permitirá al agente inteligente realimentarse y profundizar mejor sus relaciones, teniendo como consecuencia una recomendación futura más acertada.

Para todas las relaciones halladas entre los ítems del modelo de usuario se realiza el mismo proceso de inferencia de conocimiento, además del análisis de la información adicional ya mencionada que comprende el conocimiento adquirido a partir de la interacción del usuario con el sistema. Para el agente inteligente es importante que las variables a consequence a more successful future recommendation-, is entered into the model.

For all the relationships found between the items of the user model the process of inference of knowledge is performed, also analysis of the additional information mentioned above comprising the gained knowledge from user interaction with the system. For the intelligent agent it is important that entrants variables in the ranking algorithm are reliable, that is, the contents of these variables do have not missing or unusable data, and variables have relevant information on the target system, without causing redundancy of knowledge; this is why, from the analysis of the relationships and processes of inference that can be acquired from the items provided by the user as part of the user model, the most significant attributes must be chosen to become variables to input the intelligent agent algorithm.

The choice of such items in this work is made by examining model relationships and finding what attributes are most relevant to a recommendation of physical 
Table 6. Data set attributes / Atributos del set de datos

\begin{tabular}{|c|c|c|}
\hline Attribute / Atributo & Description / Descripción & Values / Valores \\
\hline IMC & $\begin{array}{l}\text { Value IMC. VNC*4 / Valor } \\
\text { IMC. VNC*4 }\end{array}$ & $\begin{array}{l}\text { Underweight, normal weight, overweight, obesity. / Bajo peso, } \\
\text { normo peso, sobrepeso, obesidad. }\end{array}$ \\
\hline Life cycle / Ciclo de vida & VNG 2 & Adolescents to adults, adults. / Adolescentes adultos, adultos \\
\hline Ethnicity / Etnia & VNG 3 & Indigenous, Afro-Colombian, other. / Indigena, afrocolombiano, otro. \\
\hline Trauma / Traumatismo & VNG 4 & $\begin{array}{l}\text { Motor, visual, auditory, without trauma. / Motriz, visual, auditivo, } \\
\text { sin traumatismo. }\end{array}$ \\
\hline $\begin{array}{l}\text { System use / Uso del } \\
\text { sistema }\end{array}$ & VNG 3 & Health, beauty, sports. / Salud, belleza, deporte. \\
\hline ECV & VNG 3 & Diabetes, hypertension without risk. / Diabetes, hipertensión, sin riesgo. \\
\hline Intervention / Intervención & $\begin{array}{l}\text { Class data set. VNG } 17 \text {, } \\
\text { Clase del set de datos. VNC } 17\end{array}$ & $\begin{array}{l}\text { Dancing, walking, physical exercises, stretching, eye exer- } \\
\text { cises, tips, personal hygiene, HIIT, Labor, tips labor, eyes } \\
\text { labor, LISS, swimming, eyes, relaxation, SCC, jogging. ' } \\
\text { Bailar, Caminar, Ejercicios_corporales, Estiramiento, Estiramiento_ojos, Extremidades, } \\
\text { Higiene_corporal, HIIT, Laborales, Laborales_extremidades, Laborales_ojos, LISS, } \\
\text { Nadar, Ojos, relajación, SCC, Trotar. }\end{array}$ \\
\hline
\end{tabular}

activity and a healthy diet. In TABLE $\mathbf{6}$, the set of data generated with the variables chosen for this case are presented; the attribute corresponds to the user model item selected to be input of data set, the description indicates the attribute type and number of options possible by attribute, and finally, the values that correspond to options that can take an attribute.

Continuing with the example of inference from the date of birth, it can be seen how, in the intelligent agent, the current age of the user gives relevant information for a recommendation, to be represented in a variable called lifecycle incoming items data set, because it is more important to work on interpreting the user's age by a nominal attribute previously analyzed by experts, and not the numerical value of the age; this nature is because the user behavior, by age, is similar in certain ranges; thus, users, depending on their age, are grouped in a life cycle of adolescent or adult. The correct choice of variables in the data set ensures the reliability of the recommendations made from the model to the user. The inference process of the intelligent agent is generalized in Figure 6 and described below.

- Learning from experience. Include all learning strategies of the process, data updates from the producer of results, joint training and preparation of new information that provides the user model.

- Data analyzer. Analyzes the data based on what the intelligent agent must to learn; in this functional block relationships between information model are specified.

- Producer results. At this point the appropriate classification algorithms are implemented according to entrantes en el algoritmo de clasificación sean confiables, es decir, que el contenido de estas variables no tenga datos faltantes o inutilizables, y que las variables tengan información relevante para el objetivo del sistema, sin causar redundancia de conocimiento; es por esto que, a partir del análisis de las relaciones y de los procesos de inferencia que se pueden adquirir de los ítems entregados por el usuario como parte del modelo de usuario, se deben elegir los atributos más significativos para que se conviertan en las variables de entrada del algoritmo del agente inteligente.

La elección de dichos ítems en este trabajo se realiza recorriendo las relaciones del modelo y encontrando qué atributos son más relevantes para una recomendación de actividad física y dieta saludable. En la TABLA 6, se presenta el set de datos generado con las variables elegidas para este caso, el atributo corresponde al ítem del modelo de usuario seleccionado para ser entrada del set de datos, la descripción indica el tipo del atributo y el número de opciones posibles por atributo y, finalmente, los valores que corresponden a las opciones que puede tomar un atributo.

Continuando con el ejemplo de inferencia a partir de la fecha de nacimiento, se puede apreciar cómo, dentro del agente inteligente, la edad actual del usuario otorga información relevante para una recomendación, al representarse en una variable llamada ciclo de vida en los elementos entrantes del set de datos, debido a que es más importante para el trabajo interpretar la edad del usuario mediante un atributo nominal previamente analizado por expertos, y no el valor numérico de la edad; esta naturaleza se da porque el comportamiento de un usuario, según su edad, es parecido en ciertos rangos; así, los usuarios, según su edad, se agrupan en un ciclo de vida adolescente o adulto. La correcta elección de las variables dentro del set de datos asegura la confiabilidad en las recomendaciones del modelo hacía el usuario. El proceso de inferencia del agente inteligente se generaliza en la Figura 6 y se describe a continuación. 


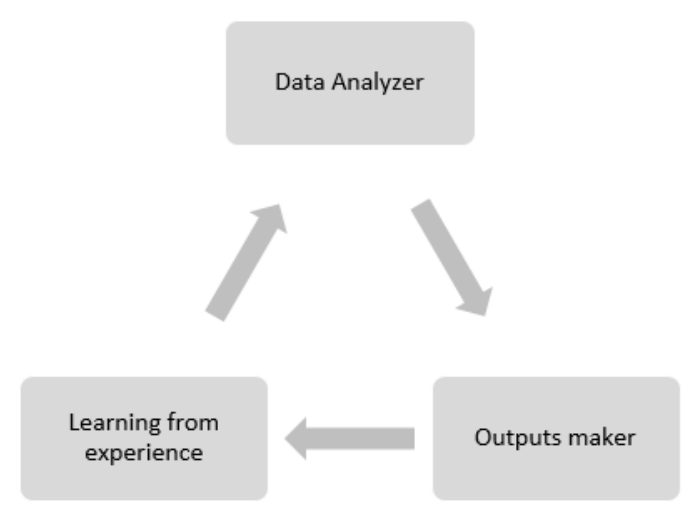

Figure 6. Interference blocks of model intelligent agent / Bloques de inferencia del agente inteligente del modelo.

- Aprendizaje de experiencia. Abarca todas las estrategias de aprendizaje del proceso, actualizaciones de datos provenientes del productor de resultados, conjuntos de entrenamientos y preparación de nueva información que brinde el modelo de usuario.

- Analizador de datos. Analiza los datos con base en lo que tiene que aprender el agente inteligente; en este bloque funcional se especifican las tablas de relaciones entre la información del modelo.

- Productor de resultados. En este punto se implementan los algoritmos de clasificación apropiados de acuerdo con el objetivo de conocimiento deseado y a las características de los datos a analizar.

\section{Arquitectura del sistema}

Este último apartado de resultados presenta la arquitectura para el sistema personalizado basado en el modelo de usuario propuesto. Teniendo como referencia la estructura general de un proceso de adquisición de nuevo conocimiento usado comúnmente en la minería de datos (Molina \& García, 2006), the desired objective knowledge and the characteristics of the data to be analyzed.

\section{System architecture}

The latter results section presents the architecture for personalized system based on the proposed user model. With reference to the general structure of a process of acquiring new knowledge commonly used in data mining (Molina \& Garcia, 2006), the necessary elements for the system architecture are contemplated. Figure 7 illustrates the way of looking at the design of an implementation that seeks to acquire new knowledge in accordance with a specific objective.

The pyramid in Figure 7 is divided into five bases. The lower communications and processing systems are shown; at this point the operating system in which it is worked and middleware that will bridge communication between internal sub-modules of the mining process it is contemplated. For the architecture proposed in this paper, a web platform is used as a communication middleware.

Climbing the pyramid are the systems of databases used to store all the information to be analyzed to generate new knowledge. The system databases include the information concerning the characterization of the user model, the multimedia content covering recommending interventions and, finally, learning obtained from user interaction with the system.

The third baseman in the pyramid of mining is the warehouse, which is defined as a deposit that structures all the information, so that it is handled in a clean and

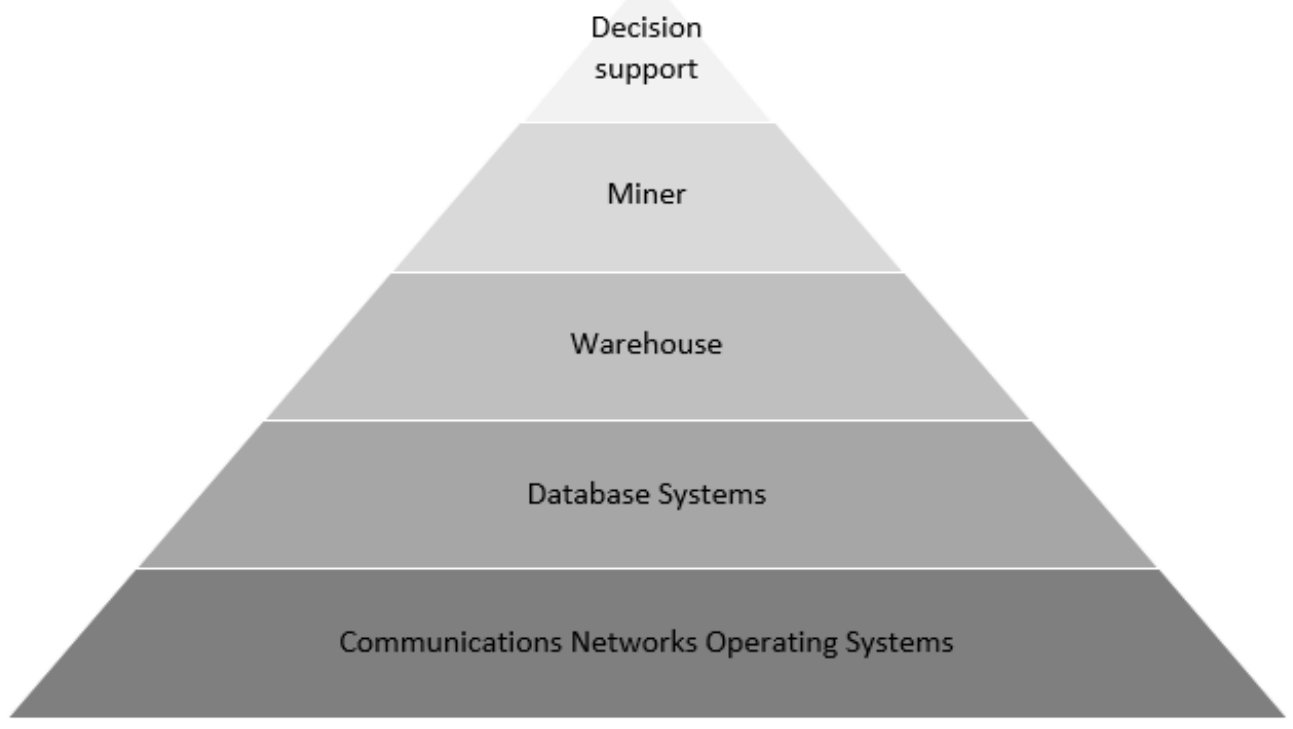

Figure 7. Pyramid Mining (Molina \& Garcia, 2006) / Pirámide de minería (Molina \& García, 2006) 
efficient manner. Within a warehouse pre-processing and modeling information required is performed when the information received comes from external sources that handle different data structures; due to the management information will be entered into the mining module in intelligent agent is present in the previously structured and controlled, the base of the pyramid can be excluded in building architecture.

Miner, the fourth base, is responsible for analyzing information that will reach decisions based on the inference results. In the reference architecture proposed mining tasks are in the intelligent agent model.

The top of the pyramid, meanwhile, refers to the categorization of interventions that ultimately will be advice for the user to practice, for behavioral change in search of healthy living.

Considering the above and based on the characteristics of the user model, the architecture described in Figure 8 is proposed, whose components are described below.

Servers. In this block there are: media servers, where they are stored, both interventions multimedia content, tested, that have been successful in promoting physical activity, and relationships metadata of each intervention, which are consulted by the intelligent agent to choose the best possible recommendation; and the database server, responsible for managing the database user model and make the relationships between data received and sent to servers.

- Control. This block consists of two servers: the smart server, where they run all tables in relations between the model items and model classification whose inference process in the user model is applied; and the server user, this contains the model characterization which will receive information from the user and will adapt to the described structure in this article.

- Sight. This block covers all media users of the system and their respective adaptation according to the category of devices.

To define the technologies to be used in this architecture, Delphi methodology was used with some parameters of DCU methodology. According Delphi, a series of metrics are raised, interviews were conducted with experts in the field and the literature of each of the possible technologies was examined; all this served as support to choose the most appropriate technology for the se contemplan los elementos necesarios para la arquitectura del sistema. La Figura 7 estructura la forma de contemplar el diseño de una implementación que busca adquirir nuevo conocimiento de acuerdo con un objetivo específico.

La pirámide de la Figura 7 se divide en cinco bases. En la inferior se muestran las comunicaciones y sistemas del proceso, en este punto se contempla el sistema operativo en el que se trabaja y el middleware que servirá de puente de comunicación entre los submódulos internos del proceso de minería. Para la arquitectura propuesta en este artículo se usa como middleware de comunicación una plataforma web.

Escalando la pirámide se encuentran los sistemas de bases de datos que sirven para almacenar toda la información que se desea analizar para generar nuevo conocimiento. Las bases de datos del sistema contemplan la información concerniente a la caracterización del modelo de usuario, el contenido multimedia que abarca las intervenciones a recomendar y, finalmente, el aprendizaje obtenido a partir de la interacción del usuario con el sistema.

La tercera base en la pirámide de minería es el warehouse, que se define como un almacén que estructura toda la información, de tal forma que se maneje de una manera limpia y eficaz. Dentro de un warehouse se realiza el pre-procesamiento y modelamiento de información, necesario cuando la información recibida viene de fuentes externas que manejan estructuras distintas en sus datos; dado que el manejo de información que se ingresará en el módulo de minería presente en el agente inteligente es controlado y estructurado previamente, esta base de la pirámide puede ser excluida en la construcción de la arquitectura.

Miner, la cuarta base, se encarga del análisis de la información que permitirá llegar a la toma de decisiones con base en los resultados de inferencia. Dentro de la arquitectura de referencia propuesta, las labores de minería se expresan en el agente inteligente del modelo.

La punta de la pirámide, por su parte, hace referencia a la categorización de las intervenciones que al final se aconsejaran al usuario practicar, para el cambio conductual en busca de vivir saludablemente.

Teniendo en cuenta lo anterior y con base en las características del modelo de usuario, se propone la arquitectura descrita en la Figura 8, cuyos componentes se describen a continuación.

- Servidores. En este bloque se encuentran: los servidores de multimedia, donde se almacenan, tanto las intervenciones de contenidos multimedia, probados, que han sido exitosos en la promoción de actividad física, y las relaciones de metadatos de cada intervención, las que son consultadas por el agente inteligente para elegir la mejor recomendación posible; y el servidor de base de datos, encargado de gestionar las bases de datos del modelo de usuario y realizar las relaciones entre los datos recibidos y enviados a los servidores.

- Control. Este bloque consta de dos servidores: el servi- 


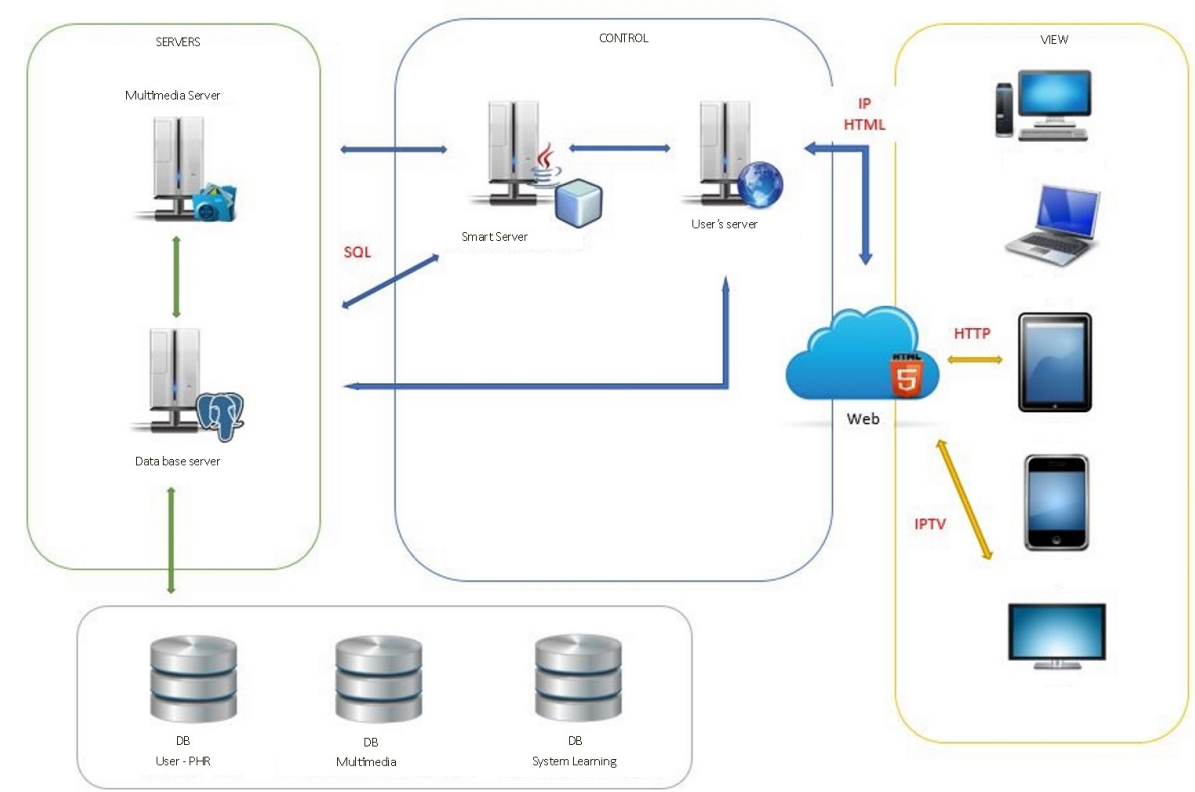

Figure 8. Computer system architecture / Arquitectura Computacional del Sistema

dor inteligente, donde se ejecutan todas las tablas de relaciones entre los ítems del modelo y se aplica el modelo de clasificación que tiene como el proceso de inferencia en el modelo de usuario; y el servidor de usuario, que contiene la caracterización del modelo que recibirá la información proveniente del usuario y la adecuará a la estructura descrita en este artículo.

- Vista. Este bloque abarca todos los medios de comunicación del usuario con el sistema y su respectiva adaptación de acuerdo con la categoría de dispositivos.

Para definir las tecnologías a usar en esta arquitectura, se usó la metodología Delphi junto con algunos parámetros la metodología DCU. De acuerdo con la primera, se planteó una serie de métricas, se realizaron entrevistas con expertos en el tema y se revisó la literatura de cada una de las posibles tecnologías; todo esto sirvió de apoyo para elegir la tecnología más conveniente para la arquitectura presentada, teniendo en cuenta parámetros de calidad y facilidad de comunicación entre los componentes. Algunas de las tecnologías seleccionadas para la arquitectura son:

- PostgreSQL como gestor de bases de datos.

- Netbeans como entorno de desarrollo y Java como lenguaje de programación.

- JBoss como servidor de aplicaciones.

- HTML5 como lenguaje de etiquetado para páginas web.

El bloque de vista contiene varios medios de acceso por los cuales el usuario es capaz de interactuar con el sistema personalizado. Es significativo que el diseño de la plataforma Web tenga características responsivas e impactantes en el usuario, como la elección de los colores dentro la plataforma -y el tipo de letra y su avatar, entre otros--, ya que el efecto visual debe architecture presented, taking into account parameters of quality and ease of communication between components. Some of the selected technologies for architecture are:

- PostgreSQL as database manager.

- Netbeans as development environment and Java as programming language.

- JBoss as an application server.

- HTML5 as markup language for web pages.

The block view contains several access means by which the user can interact with the personalized system. It is significant that the design of the Web platform has responsive and impressive features on the user, such as the choice of colors inside the platform and the font and avatar, among others, because the visual effect must influence the user to perform physical activity and follow the diet.

For this research project, using the DCU methodology, an interview was conducted with a group of people in order to determine what colors referenced to health. TABLE 7 shows, as a result of this consultation, which colors people have as a reference when talking about physical activity and a healthy diet.

The results show greater preference for blue and green. In reviewing the literature on the subject and consulting with experts it is concluded that both the blue and green colors are considered to be associated with health ser- 
vices according to human psychology regarding colors. Therefore, for a combination of the personalized system a blue and green mix called teal is used; thus, from the view block, the user is influenced by the concepts of good habits and healthy lifestyle.

\section{Conclusions and future work}

Half of the items listed were selected because of the comparison made between them through the metrics defined, where better relationships between items were found, which allows the system to have an understanding before being used by the user; thus, time zero, considered the starting point of the system, can be enough information to make inferences and make initial recommendations, based on these items.

Thanks to the relations of inference obtained from the elements of the user model, the system can learn the characteristics inherent in the user personality more efficiently, so that the personalization process is increasingly accurate and adequate.

The user model ensures better level of adherence from the user to the system, since the adjustments made by the model approach, in a more friendly way, to the personal interests of the user. As an effect of a better adherence, it is possible expect a better promotion of healthy habits and lifestyles, because it might conclude in processes of change of conduct in preset patterns, such as the transtheoretical model of behavior change (Tuah et al., 2011).

Because the user model is compliant with the ISO / TR 14292 standard, the organization and structure of information gives interoperability and security guarantees. It provides interoperability because the model is supported on a standard model; security and privacy of data, because of the knowledge that the system obtains from the user, their knowledge data and lifestyle, is personal and private.

From the DCU methodology, the relationships and inferences user model allows us to obtain a wider knowledge of people, from the key information data, without the system requiring invasive information.

The user model is the key to properly choosing the technologies used in the implementation of a personalized system, because if there are no reliable data structures, personalization cannot be achieved

The proposed architecture is generic for any personalized system that requires recommends multimedia in-
Table 7. Results of interview / Resultados de entrevista

\begin{tabular}{llll}
\hline \multirow{2}{*}{ Golor / } & \multicolumn{2}{c}{ Gender / Género } & Total \\
\cline { 2 - 5 } & $\begin{array}{c}\text { Female } \\
\text { Femenino }\end{array}$ & $\begin{array}{c}\text { Male } \\
\text { Masculino }\end{array}$ & $\left(\sum=\mathbf{2 1}\right)$ \\
\hline Purple / Morado & 2 & 0 & 2 \\
\hline Blue / Azul & 3 & 4 & 7 \\
\hline Green / Verde & 3 & 4 & 7 \\
\hline White / Blanco & 1 & 1 & 2 \\
\hline Red / Rojo & 0 & 2 & 2 \\
\hline Pink / Rosado & 1 & 0 & 1 \\
\hline
\end{tabular}

influenciar al usuario a la realización de actividad física y dieta.

Para este proyecto de investigación se realizó, mediante la metodología DCU, una entrevista a un grupo de personas con el fin de determinar qué colores referencian a la salud. La TABLA 7 muestra, como resultado de esta consulta, qué colores tiene la gente como referencia al hablar de actividad física y dieta saludable.

Los resultados muestran mayor predilección por los colores azul y verde. Al revisar la literatura al respecto y consultar con expertos se concluye que, tanto el azul como el verde son considerados colores asociados a los servicios de salud de acuerdo con la psicología humana en los colores. Por esta razón, para el sistema personalizado se utiliza una combinación del azul y el verde denominada teal; así, desde el bloque de vista, el usuario es influenciado en los conceptos de buenos hábitos y estilo de vida saludable.

\section{Conclusiones y trabajo futuro}

La mitad de los ítems contemplados fueron seleccionados debido a la comparación hecha entre ellos por medio de las métricas definidas, donde se encontraron mejores relaciones entre ítems, lo que le permite al sistema tener un conocimiento antes de ser utilizado por el usuario; de esta manera, el tiempo cero, considerado como el punto de partida del sistema, puede tener información suficiente para realizar inferencias y dar recomendaciones iniciales, con base en dichos ítems.

Gracias a las relaciones de inferencia que se obtienen de los elementos del modelo de usuario, el sistema puede aprender de las características inherentes a la personalidad del usuario de manera más eficiente, para que el proceso de personalización sea cada vez más exacto y adecuado.

El modelo de usuario garantiza mayor adherencia del usuario hacia el sistema, ya que los ajustes realizados por el modelo se acercan, de una forma más amigable, a los intereses personales del usuario. Al ganar adherencia se garantizaría una mejor promoción de hábitos y estilos de vida saludables, pues podría concluir procesos de cambio de conducta establecidos en modelos predeterminados, como el modelo transteórico de cambio de comportamiento (Tuah et al., 2011).

Dado que el modelo de usuario se encuentra conforme a la norma ISO/TR 14292, la organización y estructura de la información garantiza interoperabilidad y seguridad. Interope- 
rabilidad porque el modelo está soportado en un modelo estándar; seguridad y privacidad de los datos, pues el conocimiento que el sistema obtiene del usuario, correspondiente a sus datos y estilo de vida, es personal y privado.

Desde la metodología DCU, las relaciones e inferencias del modelo de usuario permiten obtener un conocimiento más amplio de él, a partir de los datos claves del mismo, sin necesidad de que el sistema sea invasivo en la toma de información.

El modelo de usuario es la base fundamental para escoger adecuadamente las tecnologías a usar en la implementación de un sistema personalizado, ya que si no existen estructuras de información confiables no es posible conducir a una personalización.

La arquitectura propuesta es genérica para cualquier sistema personalizado que requiera recomendar intervenciones multimedia de actividad física y dieta saludable, por lo tanto es flexible y puede ser usada en otros sistemas similares.

Como trabajo futuro queda implementar el modelo de usuario para el sistema personalizado que promocione actividad física y dieta saludable, y realizar su evaluación usando métodos de evaluación en Ingeniería de Software siguiendo la metodología DESMET.

\section{Agradecimientos}

Este trabajo fue realizando en el marco del trabajo de doctorado Sistema adaptativo como apoyo a la promoción de actividad física y alimentación saludable, financiado por Colciencias. $\mathbf{S} \mathbf{T}$ terventions of physical activity and healthy diet, so it is flexible and can be used in other similar systems.

Future work will be to implement the user model for a personalized system that promotes physical activity and a healthy diet, and to evaluate it using evaluation methods in software engineering following the DESMET methodology.

\section{Acknowledgment}

This work was done using the framework of the doctoral work adaptive system to support the promotion of physical activity and healthy eating, funded by Colciencias. SR

\section{References / Referencias}

Barua, D., Kay, J., Kummerfeld, B., \& Paris, C. (2011, November). Theoretical foundations for user-controlled forgetting in scrutable long term user models. En Proceedings of the 23rd Australian Computer-Human Interaction Conference (pp. 4049). New York, NY: ACM.

Brun, Y. (2009). Software Engineering for Self-Adaptive Systems: A Research Roadmap. In Lecture Notes in Computer Science: Vol. 5525. Software Engineering for Self-Adaptive Systems (pp.48-70). Berlin Heidelberg: Springer.

Buttussi, F. (2008, September). A user-adaptive and context-aware architecture for mobile and desktop training applications. En Proceedings of the 10th international conference on Human computer interaction with mobile devices and services ( $\mathrm{pp}$. 543-543). New York, NY: ACM.

Buttussi, F., \& Chittaro, L. (2008). MOPET: A context-aware and user-adaptive wearable system for fitness training. Artificial Intelligence in Medicine, 42(2), 153-163.

Carreño, M. (2009). El método Delphi: cuando dos cabezas piensan más que una en el desarrollo de guías de práctica clínica. Revista Colombiana de Psiquiatría, 38(1), 185-193.

Du, H., Youngblood, G. M., \& Pirolli, P. (2014). Efficacy of a Smartphone System to Support Groups in Behavior Change Programs. En Proceedings of the Wireless Health 2014 on National Institutes of Health (pp.1-8). New York, NY: ACM.

Feisst, M., dos Santos, D. R., Mitic, J., \& Christ, A. (2005). Adaptive heterogeneous learning system. Retrieved from http:// www.mlearn.org/mlearn2005/CD/papers/Feist.pdf

González, H. M., Duque, N. D., \& Ovalle, D. A. (2009). Modelo del estudiante para sistemas adaptativos de educación virtual. Avances en Sistemas e Informática, 5(1), 199-206.

What is a personal health record? (2013, May 2). [HealthIT blog]. Retrieved from: http://www.healthit.gov/providers-professionals/faqs/what-personal-health-record

Ifeachor, E., Hu, P., Sun, L., Hudson, N., \& Zervakis, M. (2009, July). Bioprofiling over grid for personalized eHealthcare for AD. In Proceedings of the 2009 conference on Computational Intelligence and Bioengineering: Essays in Memory of Antonina Starita (pp. 155-165). Amsterdam, The Netherlands: IOS.

International Organization for Standardization [ISO]. (2010). ISO 9241-210:2010. Ergonomics of human-system interaction - Part 210: Human-centered design for interactive systems. Geneva, Switzerland: ISO

International Organization for Standardization [ISO]. (2012). ISO/TR 14292:2012. Personal health records - definition, scope and context. Geneva, Switzerland: ISO

Leka, S. (2004). La organización del trabajo y el estrés: estrategias sistemáticas de solución de problemas para empleadores, personal directivo y representantes sindicales. Geneva, Switzerland: WHO. 
Luo, G., Tang, C., \& Thomas, S. B. (2012). Intelligent personal health record: experience and open issues. Journal of medical systems, 36(4), 2111-2128.

Martins, A. C., Faria, L., De Carvalho, C. V., \& Carrapatoso, E. (2008). User modeling in adaptive hypermedia educational systems. Journal of Educational Technology \& Society, 11(1), 194-207.

Molina, J. \& García, J. (2006). Técnicas de análisis de datos: aplicaciones prácticas utilizando Microsoft Excel y Weka. Retrieved from: http://www.giaa.inf.uc3m.es/docencia/li/ADatos/apuntesAD.pdf

Meyer, J., Çakır-Turgut, E., \& Helmer, A. (2012). Supporting a healthy lifestyle by re-using personal online data. ACM SIGHIT Record, 2(1), 13-13.

Slootmaker, S.M., Paw, M.J.C.A., Schuit, A.J., Seidell, J.C., \& Van Mechelen, W. (2005). Promoting physical activity using an activity monitor and a tailored web-based advice: design of a randomized controlled trial [ISRCTN93896459]. BMC Public Health, 5(1), 134.

Tuah, N., Amiel, C., Qureshi, S., Car, J., Kaur, B., \& Majeed, A. (2012). Modelo transteórico de modificación dietética y ejercicio físico para la pérdida de peso en adultos con sobrepeso y obesos. Revista Médica Clínica Las Condes, 23(2), 201-202.

Universidad Minuto de Dios [Uniminuto]. (2014, Sept. 10). Calidad y hábitos de vida [blog Uniminuto]. Retrieved from: http://www.uniminuto.edu/web/bienestaruvd/vida-saludable/-/asset_publisher/HBJfz6IGSN46/content/calidad-y-habitosde-vidahttp://www.uniminuto.edu/web/uvd/-lestilos-de-vida-saludables

Weibelzahl, S. (2001). Evaluation of adaptive systems. In Lecture Notes In Computer Science: Vol.2109. User Modeling 2001, (pp. 292-294). Berlin Heidelberg: Springer.

World Health Organization [WHO]. (2012). Campaña del Día mundial de la salud 2012 [blog - WHO]. Retrieved from: http:// www.who.int/world-health-day/2012/toolkit/campaign/es/

Yadav, N., \& Poellabauer, C. (2012, October). An architecture for personalized health information retrieval. In Proceedings of the 2012 international workshop on Smart health and wellbeing (pp.41-48). New York, NY: ACM. 


\section{CURRICULUM VITAE}

Carolina Rico Olarte Engineering in Electronics and Telecommunications student from the Universidad del Cauca, Colombia, with expertise in software development and personal health records (PHR), and particular interest in knowledge management from ICT. Currently she is working with personalized systems habits and promoting healthy lifestyles. / Estudiante de Ingeniería en Electrónica y Telecomunicaciones de la Universidad del Cauca, Colombia, con conocimientos en desarrollo de software y registros personales de salud (PHR), e interés particular en gestión del conocimiento desde las TIC. Actualmente trabaja con sistemas personalizados en promoción de hábitos y estilos de vida saludables.

Edwar Javier Girón Buitrón Engineering in Electronics and Telecommunications student from the Universidad del Cauca, Colombia, qualified in classification techniques, gamification and data processing, and particular interest in KDD processes and gamification in education and health. Currently he is working with custom systems habits and promoting healthy lifestyles. / Estudiante de Ingeniería en Electrónica y Telecomunicaciones de la Universidad del Cauca, Colombia, con conocimientos en técnicas de clasificación, gamificación y procesamiento de datos, e interés particular en procesos de KDD y gamificación en Educación y Salud. Actualmente trabaja con sistemas personalizados en promoción de hábitos y estilos de vida saludables.

Gineth Magaly Cerón Ríos Electronics and Telecommunications Engineering, Master in Telematics Engineering and candidate to Ph.D. in Telematics Engineering of the Universidad del Cauca, Colombia. His areas of interest are the telematic services, cloud services and software product quality. She is currently a researcher at the line of e-Health in the development of projects to promote habits and healthy lifestyles supported in ICT, and modeling and implementation of personalized systems to health. / Ingeniera en Electrónica y Telecomunicaciones y Magíster en Ingeniería Telemática de la Universidad del Cauca, es candidata a Doctora en Ingeniería Telemática en la Universidad del Cauca. Sus áreas de interés son los servicios telemáticos, los servicios en la nube y la calidad de producto software. Actualmente es investigadora en la línea de e-Salud, en el desarrollo de proyectos orientados a la promoción de hábitos y estilos de vida saludables soportados en TIC, y en modelado e implementación de sistemas personalizados para salud.

Diego Mauricio López Gutierrez Electronics and Telecommunications Engineer (1999) and Master in Telematics (2005) from the Universidad del Cauca, and Ph.D. in Biomedical Sciences area for Health Information (2008), University of Regensburg, Germany. Since 2000 he has been professor of the Department of Telematics at the Universidad del Cauca, where he leads the research in computer and telecommunications applied to health (e-health). He is a member of the Board of the HL7 Colombia Foundation. He has participated and worked as reviewer and member of the program committee of conferences and journals in the area of e-health and has published more than 60 papers in journals and national and international conferences. His main areas of interest are interoperability and information systems architectures, software development processes, standards in e-health, information systems in public health and mobile health (m-Health). / Ingeniero en Electrónica y Telecomunicaciones (1999) y Magíster en Telemática (2005) de la Universidad del Cauca, y Doctor en Ciencias Biomédicas área Informática para la Salud (2008) de la Universidad de Regensburg, Alemania. Desde el año 2000 es profesor del Departamento de Telemática de la Universidad del Cauca, donde lidera la línea de investigación en Informática y Telecomunicaciones aplicada a la Salud (e-Salud). Es miembro de la Junta Directiva de la Fundación HL7 Colombia. Ha participado y colaborado como revisor y miembro del Comité de Programa de Conferencias y Revistas en el área de e-Salud y ha publicado más de 60 artículos en revistas y congresos nacionales e internacionales. Sus principales áreas de interés son la interoperabilidad y arquitecturas en sistemas de información, los procesos de desarrollo software, los estándares en e-Salud, los sistemas de información en salud pública y la salud móvil (m-Health). 